МЕТОДЫ

\title{
Interaction of cyanine dyes with nucleic acids. 3. The use of new cyanine dyes Cyan 13 and Cyan 40 for detection of nucleic acids in agarose gel
}

\author{
Sergiy M. Yarmoluk, Igor Ya. Dubey ${ }^{1}$ \\ Institute of Molecular Biology and Genetics, National Academy of Sciences of Ukraine \\ 150 Zabolotnogo str., Kyiv, 252143, Likraine \\ 1 \\ Institutc of Biocrganic Chemistry and Petrechemistry, National Academy of Sciences of Ukraine \\ 1 Murmanska str., Kyiy, 253660, Ukraine
}

Detection of double stranded DNA (dsDNA) and single-strtnded DNA (ssDNA) and RNA with two new cyanine dyes Cyan 13 and Cyan 40 is reported. Cyan 13 and Cyan 40 bind to nucleic ucids to form a stable fluorescent complexes and can be used for the detecticn of DNA and RNA samples separated by gel electrophoresis. Sensitivity of detection is comparable to tl at for ethidium bromide (EtBr), a common nucluic acid staining dye.

Materials and Methods DNA and RNA preparation. Double-stranded plasmid DNAs $p B R 322$ and $p U C 18$ were isolated by standard alkaline lysis method of Birnboim [1]. Linear plasmid DNA pUC18 was obtained by digestion with BamHI restrictase. Closed circular single-stranded M13mpl DNA (M13 ssDNA) was obtained from USB (USA). Total RNA was extracted from rat liver tissue by guanidinium thiocyanate-phenol method according to Chomczynski et al. [2].

Agarose gel electrophoresis and staining of nucleic acids. $0.8 \%$ Agarose gels were prepared in standard TAE buffer $(40 \mathrm{mM}$ Tris-acctate, $1 \mathrm{mM}$ EDTA, pH 8.0) [3]. DNA and RNA samples in TAE buffer were loaded on the gel after adding tracking dyes xylene cyanole and bromophenole blue in $30 \%$ glycerol to concentration $0.025 \%$. Scparations were carricd out at $10 \mathrm{~V} / \mathrm{cm}$. DNA and RNA gels were stained after electrophoresis in the solution of Cyan 13, Cyan 40 or $\operatorname{EtBr}(1 \mu \mathrm{g} / \mathrm{ml})$ for $30 \mathrm{~min}$.

Fluorescence detection of DNA and RNA in agarose gels. Detection of DNA-dye and RNA-dye complexes was performed with UV-transilluminator 2011 Macrovue ( LKB », Sweden) at $524 \mathrm{~nm}$. The gels were photographed using orange filter.

(C) S. M YAKMOLCX. I. Ya. DE:BEY, 19497
Results and Discussion. The use of non-isotopic detection techniques in biology and medicine is an attractive alternative to radioactive detection methods. Cyanine dyes are now widely used as fluorescence detection probes. Monomethyne cyanine dyes are weakly fluoresceat in ree state but show strong fluorescence upon binding to DNA or RNA, and some of these reagents are the most sensitive nucleic acid stains currently available $[4,5]$. A series of new fluorescent cyanine dyes with improved spectroscopic properties including Cyan 13 [6] and Cyan 40 17) has been recently developed in our laboratory (Fig. 1).

In this communication we demonstrate that Cyan 13 and Cyan 40 can be successfully used for DNA and RNA detection in the standard procedures. Dycs bind efficiently 10 different forms of DNA - covalently closed circular and linear dsDNA and ssDNA, as well as to various RNA types - ribosomal RNA, mRNA and tRNA, forming stable fluorescent complexes.

In Fig. 2 is shown the comparison of DNA staining in agaroise gel with Cyan 13, Cyan 40 and EtBr. It was show'n that fluorescence of Cyan 13 and Cyan 40 complexes with linear dsDNA and circular M13 ssDNA (lanes $/$ and 3, respectively) was comparable wit that of $\mathrm{EtBr}$. 


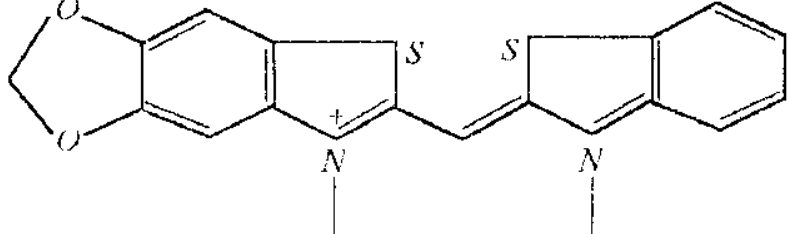

OTOS

(van 13

Fig. 1. The chemical structure of cyanine dyes
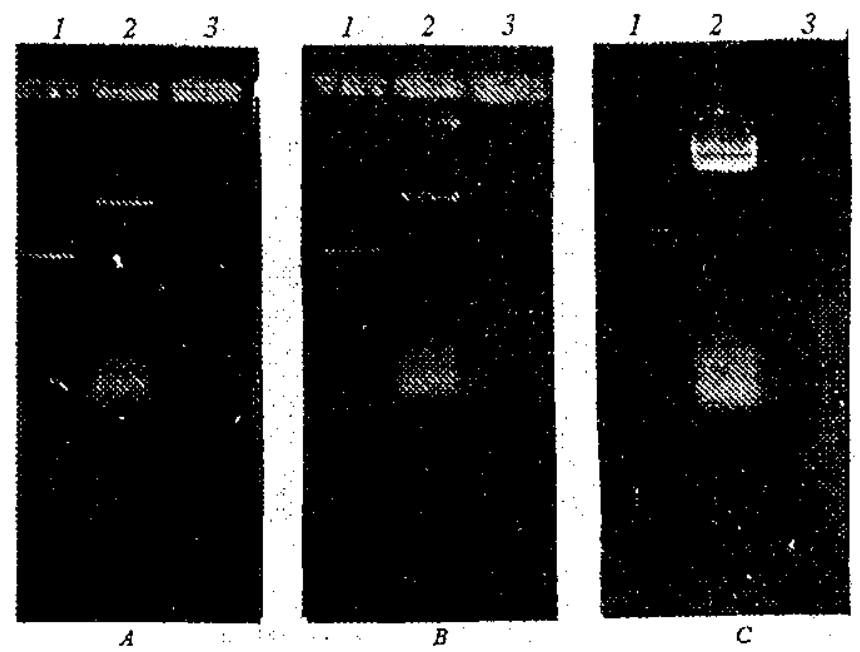

Fig. 2. Detection of DNA in agarose, gels after electrophoresis: lane $1-200 \mathrm{ng}$ of dSONA pUCI8 linearized with Bamlll restrictase; lane $2-300 \mathrm{ng}$ of intact $p B R 322$ dsDNA; lane $3-200 \mathrm{ng}$ of M13 ssDNA. Staining was made with Cyan $13(A)$, with Cyan $40(B)$ and ÈtBr (C)

But the intensity of fluorescence of $\mathrm{EtBr}$ complex with circular closed dsDNA (lane 2) was higher than those for Cyan 13 and Cyan 40. It is necessary to note that the contamination of bacterial tRNAs in samples of circular closed plasmid DNAs shined with almost equal intensity.

The fluorescence intensity of Cyan 13 and Cyan 40 complexes with RNA is enough high. As is shown in Fig. 3, all types of RNA - ribosomal RNA, mRNA and TRNA - can be detected in total RNA samples. Both 28S and 18S rRNAs were detectable in the gels stained with Cyan 13 and Cyan 40 , as well as stained with EtBr. The fluorescence of RNA complexes with Cyan 40 was lower as compared with two other dyes.

The colours of fluorescence of RNA and DNA

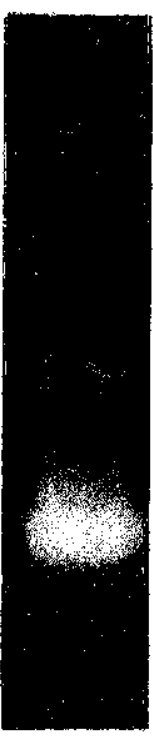

A<smiles></smiles>

OTos
Cyan 40

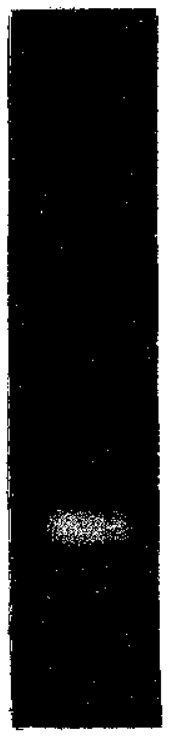

$B$

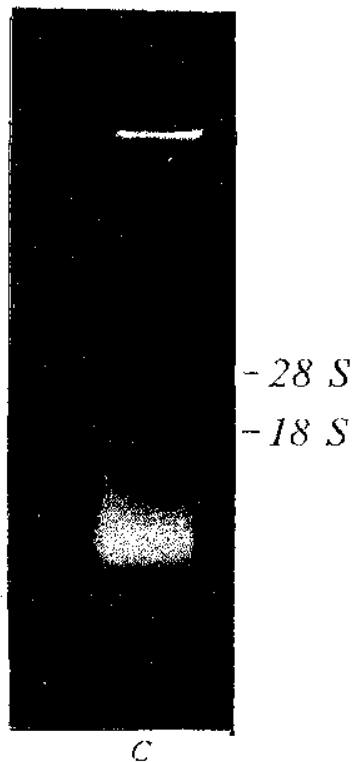

Fig. 3. Staining of RNA in agarose gels after electrophoresis with Cyan $13(A)$, Cyan $40(B)$ and $\mathrm{EtBr}(C)$. Each lane contains $5 \mu \mathrm{g}$ of total rat liver RNA. Positions of ribosomal $28 \mathrm{~S}$ and $18 \mathrm{~S}$ RNA are indicated

complexes with Cyan 13 and Cyan 40 were from blue to light green. The colour of Cyan 13 - DNA complexes was shifted to red by increasing dye concentration or time of staining. It is possible that such a change off luorescence spectrum was caused by formation of $\mathrm{H}$-aggregates (unpublished results).

I1 can be concluded therefore that two new cyanine dyes Cyan 13 and Cyan 40 can be used for DNA and RNA detection in agarose gels. 
Acknowledgements. We are indebted to Dr. Yu. Kovtun for providing the dyes and thank Ms. $V$. Koval'ska for technical assistance.

\section{С. М. Ярмолюк, I. Я. Дубей}

Взасмодія ціаніноних барвників з нуклейновими кислотами.

3. Застосування нових ціанінових барнників Cуan 13 та Суап 40 для визначення иуклеїнових кисльт в агарозних гелях

Резюме

Два пових ціанінових барвники Суап 13 ma Суап 40 було застосовано для флюоресцентної детекиї двоспіральної ДнК ma односпіральних ДНК $i$ PHК в електрофорезних гелях. чутиивість детекцї нуклеїнових кислот цими барониками схожа з такою бромистого етияію, ио звичайно використовусться dля цісї мети.

С. Н. Яриолюк, И. Я. Дубей

Взаимодейсгвие цианиновых красителей с нукленювыми кислотами. 3. Применение новых цианиновых красителей Cyan 13 и Суан 40 для определения нуклеиновых кислог B aranozhux resstx

Резюме

Два новых цианиновых красителя Суап 13 и Суап 40 применены для флюоресцентной детекци довуспиральной дНК и односпиральных ДНК и РНК в электрофорезных селя. Чувстви- тельноспь детекции нуклеиновых кислот этими красителями подобна таковой бромистого этидия, которьй обынио используется оля әтой цели.

\section{REFERENCES}

1 Birnboim H. A rapid alkaline extraction method for the isolation of plasmid DNA // Meth. Enzymol.-1983. - 100.P. 243-256.

2. Chomczynski $P$., Sacchi N. Single-step method of R.VA isolation by acid guanidinium thiocyanate - phenol - chloroform extraction // Anal. Biochem.-1987.-162.-P. 156159.

3. Maniatis $T$., Fritsch E. F., Sambrook J. Molecular cloning: A laboratory manual.-New York: Cold Spring Harbor Lab., $1982 .-545 \mathrm{p}$

4. Haughland R. P. Molecular probes. Handbook of fluorescent probes and research chemicals.-Eugene, OR., 1996.-679 p.

5. Lee $G$. L., Chen C.-H., Chiu L. A. Thiazole Orange: a new dye for reliculocyte analysis // Cytometry.-1986.-7.-P. 508-517.

6. Yarmoluk S. M., Zhyvoloup A. N., Koval'ska V. B. et al. Interaction of cyanine dyes with nucleic acids. I. Studies on monomethyne cyanine dyes as possible fluorescent probes for the detection of nucleic acids // Biopolymers and Cell-1996.-12, N 1.-P. 69-74.

7. Yarmoluk S. M., Kovalska V. B., Smirnova T. V. et al. Interaction of cyanine dyes with nucleic acids. II. Spectroscopic properties of methyleneoxy analogues of Thiazole Orange// Ibid. $-\mathrm{N} 6 . \multimap \mathrm{P} .74-81$.

Received 18.02.97 